\title{
MJMR THE DIFFERENCES IN THE AUTOGENIC RELAXATION THERAPY'S INFLUENCES ON REDUCING PAIN LEVELS IN POSTOPERATIVE SECTIO CAESARIA PATIENTS
}

\author{
Riris Andriati ${ }^{1}$, Rita Dwi Pratiwi ${ }^{{ }^{* 1}}$, Fenita Purnama Sari Indah ${ }^{2}$ \\ ${ }^{\prime}$ Widya Dharma Husada Tangerang School of Health Science, 15417, Indonesia \\ ${ }^{2}$ Kharisma Persada School of Health Science, 15417, Indonesia \\ *Corresponding Author's Email: ritadwipratiwi@wdh.ac.id
}

\begin{abstract}
Introduction: According to WHO, the average standard of sectio caesarea in a country is about $5-10 \%$ in every 1000 births in the world. One of the complications of sectio caesaria is a pain in the incision area. Nonpharmacologic pain management strategies for dealing with pain are autogenic relaxation therapy. Autogenic relaxation therapy is one of relaxation techniques where the source's is in the inside of our self in form of a short sentence that can make the mind peaceful. The objective of the research is to evaluate the differences effect of autogenic relaxation therapy to reduce pain level on postoperative sectio caesaria patients at Ciputat Buah Hati Hospital. Method: The research design used was quasy experimental research with the randomized pretestposttest with control group design involving 50 postoperative sectio caesarea patients consisted of 25 respondents as intervention group and 25 respondents as control group. Sampling technique used was non probability sampling namely purposive sampling techniques. Result: The average of pain levels at intervention group after they had been given autogenic relaxation therapy was 2,88 and at control group was 3,48. A result of Mann Whitney U test, showed $p$-value $0,024<\alpha 0,05$. Conclusion: The differences pain levels in postoperative sectio caesaria patients after they had been given autogenic relaxation therapy between intervention group and control group showed that there was some different effects of giving autogenic relaxation therapy to reduce pain levels at postoperative sectio caesaria patients at Ciputat Buah Hati Hospital.
\end{abstract}

Keywords: Autogenic Relaxation Therapy, Pain Levels

\section{INTRODUCTION}

According to the research which conducted by Sriyanti (2016), the average standard of sectio caesarea in a country is about $5-10 \%$ in every 1000 births in the world. However, in the last 20 years, Indonesia has experienced an increase in the proportion of cesarean sections from $5 \%$ to $20 \%$. In general the number of cesarean section deliveries in government hospitals is around $11 \%$ of total deliveries, while private hospitals can be very high, which is more than $30 \%$ of total deliveries.

Based on Balitbang Health Ministry of Indonesia in 2013 , the birth of sectio caesaria in Indonesia was $9.8 \%$. The Riskesdas data also showed the number of deliveries with sectio caesaria in 2013, in Banten Province, which was $12.1 \%$ of all deliveries. And Basic Health Research, Banten Province data in 2013 showed
South Tangerang city as the highest proportion of deliveries with sectio caesaria which amounted to $21.9 \%$. The medical record of Buah Hati Ciputat Hospital recorded that the number of sectio caesaria patients in 2016 are as many as 1,687 people or around $63 \%$ of all deliveries.

Postoperative sectio caesaria patients will usually feel the pain of the surgical wound after a few hours after surgery in line with the recovery of the anesthetic effect from the mother's body. This is often complained of by postoperative mothers in caesarean section. Pain is a condition in the form of unpleasant feelings, it is very subjective because each person feels different pain in terms of scale or level, and only that person can explain or evaluate the pain they experience (Hidayat and Uliyah, 2016).

To relieve pain, nurses need to provide appropriate pain 
management for each individual. And one of the techniques of deep relaxation techniques and guided imagination to relieve pain is by giving autogenic therapy. Autogenic relaxation technique is one of selforiginating relaxation techniques in the form of words or short sentences or thoughts that can make the mind peaceful. Autogenic relaxation is done by imagining oneself in a state of peace and calm, focusing on breathing regulation and heartbeat (Farada and Amalia, 2011).

From the preliminary survey conducted by the researchers by interviewing postoperative sectio caesaria patients, it was found that almost all respondents complained of pain in the surgical wound with a pain scale of 4-6 (moderate pain). Complaints of pain especially felt when the effects of anesthesia begin to disappear, between 2 to 4 hours after surgery and it's getting sicker and worse. From the survey, it was also found that 4 out of 10 respondents said that in order to reduce pain, respondents performed deep breathing relaxation techniques as taught by nurses during education prior to surgery. However, 6 of all respondents, chose to hold pain by not moving which can cause increased pain. Based on the above background, the researchers were interested in examining with the title of The Differences in the Autogenic Relaxation Therapy's Influences on Reducing Pain Levels in Postoperative Sectio Caesaria Patients at Ciputat Buah Hati Hospital.

\section{METHODOLOGY}

The research design of this study is Quasy Experimental with the Randomized Pretest-Posttest with Control Group Design approach. This method was used to compare the results of the intervention of two groups, namely the control group and the intervention group, both of them were measured before and after the intervention of autogenic relaxation therapy (Yusuf, 2014).

The population in this study was postoperative sectio caesarea mothers at Buah Hati Hospital Ciputat. The total samples were 50 respondents, consisted of 25 respondents in the intervention group and 25 respondents in the control group. The number of samples is obtained by a calculation using the formula of the numerical analytical sample size of unpaired (Dahlan, 2013). The sampling technique uses non probability sampling in the form of purposive sampling technique.

The method of data collection in this study began with the researchers gave the respondents an explanation of autogenic relaxation therapy including the manner, benefits and time of implementation. Respondents who were willing to participate in the research would be asked by the researchers to sign the consent form in the form of informant consent. The researchers conducted the research in two stages at once, namely the first stage carried out in the intervention group and the second stage in the control group. Before giving the therapy, the researcher identified the pain level of the respondent. Pain assessment uses NRS (Numerical Rating Scale) with interview guidelines and recording on the pain observation sheet. Autogenic relaxation therapy was carried out between 07.00 WIB until 17.00 WIB every day for 3 days. The first day of therapy was done 4-6 hours postoperative sectio caesaria, the second day was done 24 hours postoperative sectio caesaria and the third day 24 hours from the second day. It's reidentifeid pain levels after treatment with NRS pain assessment. In the control group, there was no treatment with autogenic relaxation therapy, the respondents only followed the nursing care program in force at the hospital where the study took place. The control group was observed and pain levels were recorded at the same time as the intervention group.

\section{RESULTS AND DISCUSSION}

The Overview of Pain Levels before the treatment of Autogenic Relaxation Therapy in Postoperative Sectio Caesaria Patients at Ciputat Buah Hati Hospital

Based on the level of pain before the autogenic relaxation therapy in the intervention group, it was found that respondents who experienced moderate pain were 8 respondents $(32 \%)$, controlled severe pain as many as 17 respondents $(68 \%)$. And the level of pain before autogenic relaxation therapy in the control group, it's found that the respondents who experienced moderate pain are 8 respondents $(32 \%)$, controlled severe pain are as many as 17 respondents $(68 \%)$.

In theory, (Heriana, 2014) a pain in general can be defined as an uncomfortable feeling, both mild and severe. Pain is very individual and cannot be measured subjectively, and only patients can feel the pain. There 
are several pain stimuli (Hidayat, 2016) including the presence of trauma to body tissues, for example due to surgery due to tissue damage and irritation directly to the receptors.

Pain after surgery was felt by some respondents. According to the researchers, this is also due to the anesthetic effect that has begun to disappear 4-6 hours postoperatively. Controlled severe pain was felt by almost all respondents, both the intervention group and the control group. While a small proportion of respondents experienced moderate pain after surgery. According to the researchers, this could occur because each respondent both the intervention group and the control group had not been given treatment, in addition to the education of deep breathing therapy which became the hospital's operational standard, so the results showed that most respondents experienced severe controlled pain and a small proportion experience moderate pain.

The Overview of Pain Levels after the treatment of Autogenic Relaxation Therapy in Postoperative Sectio Caesaria Patients at Ciputat Buah Hati Hospital

Based on the level of pain after autogenic relaxation therapy in the intervention group, respondents who experienced moderate pain were 5 respondents $(20 \%)$ and mild pain were 20 respondents $(80 \%)$. While the level of pain in the control group was found, respondents who experienced moderate pain were 11 respondents (44\%) and mild pain were 14 respondents (56\%).

According to the research by Goldbeck and Schimd (2003), Hashim and Yusuf (2011) and Tiana (2014) showed that autogenic relaxation technique is one of self-relaxation techniques in the form of words or short sentences or thoughts that can make the mind calm. Autogenic relaxation is done by imagining yourself in a state of peace and calm, focusing on breathing and heart pressure. Autogenic relaxation will help the body to carry orders through autosuggestion to relax so that it can control breathing, blood pressure, heart rate and body temperature. The body feels warmth, is a result of peripheral arteries undergoing vasodilation while decreasing body muscle tension results in a mild sensation. Changes that occur during and after relaxation affect the work of the autonomic nerve. Decreased body muscle tension expedites blood circulation and can distract pain that is felt. Then it's stated there is a significant relationship between autogenic relaxation therapies with a decrease in pain level.

According to the researchers, after being given autogenic relaxation therapy treatment 3 times with a duration of 15-20 minutes for 3 consecutive days, the results were obtained that there was a decrease in the pain level. Where autogenic relaxation therapy gave the effect of distraction as well as relaxation by shifting the focus of the respondent to the pain that's felt and by imagining oneself in a state of peace and calm, so that there's a mild, comfort sensation after the therapy was carried out, so as to reduce the level of pain felt.

The Differences in the Autogenic Relaxation Therapy's Influences on Reducing Pain Levels in Postoperative Sectio Caesaria Patients at Ciputat Buah Hati Hospital

Based on the results of research showed differences in the autogenic relaxation therapy's influences on reducing pain levels. The results were obtained: the average level of pain in the intervention group after being given autogenic relaxation therapy was 2.88 and in the control group was 3.48. These data indicate that the average pain level in the intervention group is lower than the average pain scale in the control group after being given autogenic relaxation therapy. MannWhitney $\mathrm{U}$ test results showed that it's obtained p-value of $0.024<\alpha(0.05)$, this indicates that there was a significant difference in the level of pain in postoperative patients with cesarean section after being given autogenic relaxation therapy. And this showed that there was a difference in the effect of providing autogenic relaxation therapy to reduce the pain levels in patients with postoperative sectio caesaria at the Ciputat Buah Hati Hospital.

In a previous study conducted by Fithriana, Marvia and Putra in 2016 stated that autogenic relaxation is a relaxation technique that can help reduce pain done by someone. With autogenic relaxation techniques, patients can do relaxation techniques through selfsuggestion techniques (auto suggestive), by making changes in themselves, can also regulate the appearance of emotions.

According to the researchers, this shows that autogenic relaxation techniques can provide a distraction effect 
by shifting the focus of the respondent to the pain felt by following the relaxation steps and the relaxing effect by imagining oneself in a state of peace and calm, so that a sensation of comfort arises after the therapy is done, and effect on the state of pain by reducing the level of pain felt by patients undergoing sectio caesaria.

Table 1: Intervention Group's Frequency Distribution Category of Pain Levels before Autogenic Relaxation Therapy at Ciputat Buah Hati Hospital

\begin{tabular}{|c|c|c|}
\hline Pain Levels & Frequency & $\mathbf{\%}$ \\
\hline $\begin{array}{c}\text { Controlled severe pain } \\
\text { (pain scale 7-9) }\end{array}$ & 17 & 68 \\
\hline $\begin{array}{c}\text { Moderate pain (pain } \\
\text { scale 4-6) }\end{array}$ & 8 & 32 \\
\hline Total & 25 & 100 \\
\hline
\end{tabular}

Table 2: Control Group's Frequency Distribution by Category of Pain Levels before Autogenic Relaxation Therapy at Ciputat Buah Hati Hospital

\begin{tabular}{|c|c|c|}
\hline Pain Levels & Frequency & \% \\
\hline $\begin{array}{c}\text { Controlled severe pain } \\
\text { (pain scale 7-9) }\end{array}$ & 17 & 68 \\
\hline $\begin{array}{c}\text { Moderate pain (pain } \\
\text { scale 4-6) }\end{array}$ & 8 & 32 \\
\hline Total & 25 & 100 \\
\hline
\end{tabular}

Table 3: Intervention Group's Frequency Distribution by Category of Pain Levels after A utogenic Relaxation Therapy

\begin{tabular}{|c|c|c|}
\hline Pain Levels & Frequency & \% \\
\hline $\begin{array}{c}\text { Moderate pain (pain } \\
\text { scale 4 -6) }\end{array}$ & 5 & 20 \\
\hline Mild pain (pain scale 1-3) & 20 & 80 \\
\hline Total & 25 & 100 \\
\hline
\end{tabular}

Table 4: Control Group's Frequency Distribution by Category of Pain Levels after Autogenic Relaxation Therapy

\begin{tabular}{|c|c|c|}
\hline Pain Levels & Frequency & $\mathbf{\%}$ \\
\hline $\begin{array}{c}\text { Moderate pain (pain } \\
\text { scale 4 -6) }\end{array}$ & 11 & 44 \\
\hline Mild pain (pain scale 1-3) & 14 & 56 \\
\hline Total & 25 & 100 \\
\hline
\end{tabular}

Table 5: the Differences in Pain Levels before and after the Treatment of Autogenic Relaxation Therapy in the Intervention Group

\begin{tabular}{|c|c|c|c|}
\hline Pain Levels & Mean & SD & p - value \\
\hline $\begin{array}{c}\text { Pain levels before the } \\
\text { autogenic relaxation therapy }\end{array}$ & 7,16 & 1,281 & \multirow{2}{*}{0,000} \\
\cline { 1 - 2 } $\begin{array}{c}\text { Pain levels after the autogenic } \\
\text { relaxation therapy }\end{array}$ & $\begin{array}{c}2,84 \\
(1-6)\end{array}$ & 1,179 & \\
\hline
\end{tabular}

Table 6: the Differences in Pain Levels before and after the Treatment of Autogenic Relaxation Therapy in the Control Group

\begin{tabular}{|c|c|c|c|}
\hline Pain Levels & Mean & SD & p - value \\
\hline $\begin{array}{c}\text { Pain levels before the } \\
\text { autogenic relaxation therapy }\end{array}$ & 6,76 & 1,393 & \multirow{2}{*}{0,000} \\
\cline { 1 - 3 } $\begin{array}{c}\text { Pain levels after the autogenic } \\
\text { relaxation therapy }\end{array}$ & 3,48 & 0,872 & \\
\hline
\end{tabular}

Table 7: the Differences in Pain Levels of Postoperative Sectio Caesaria Patients before Autogenic Relaxation Therapy in the Intervention and Control Groups

\begin{tabular}{|c|c|c|c|c|}
\hline Variable & Groups & Mean & SD & \multirow{2}{*}{$\boldsymbol{p}_{\text {-value }}$} \\
\hline \multirow{2}{*}{ Pain levels } & Intervention & 7,16 & 1,281 & \multirow{2}{*}{0,369} \\
\cline { 2 - 4 } & Control & 6,76 & 1,393 & \\
\hline
\end{tabular}

Table 8. the Differences in Pain Levels of Postoperative Sectio Caesaria Patients before Autogenic Relaxation Therapy in the Intervention and Control Groups

\begin{tabular}{|c|c|c|c|c|}
\hline Variable & Groups & Mean & SD & \multirow{2}{*}{$\boldsymbol{p}_{\text {-value }}$} \\
\hline \multirow{2}{*}{ Pain levels } & Intervention & 2,88 & 1,236 & \multirow{2}{*}{0,24} \\
\cline { 2 - 4 } & Control & 3.48 & 0,872 & \\
\hline
\end{tabular}

\section{CONCLUSION}

Based on the results of the study it can be concluded that the level of pain before being given the autogenic relaxation therapy in postoperative sectio caesaria patients at the Ciputat Buah Hati Hospital results: most of the respondents experienced controlled severe pain that was as much as $68 \%$ of respondents both in the intervention group and the control group. While moderate pain was felt by $32 \%$ of respondents in the intervention group and the control group. The level of 
pain after being given autogenic relaxation therapy in postoperative sectio caesaria patients at the Ciputat Buah Hati Hospital results are obtained: most respondents experienced mild pain are as much as $80 \%$ of respondents in the intervention group and $56 \%$ of respondents in the control group. While moderate pain was felt by $20 \%$ of respondents in the intervention group and $44 \%$ of respondents in the control group. There were differences in the autogenic relaxation therapy's influences on reducing pain levels in postoperative sectio caesaria patients at the Ciputat Buah Hati Hospital, with a $p$-value of 0.024 .

\section{ACKNOWLEDGMENT}

This research was supported by Mr. M. Hasan. And then, thank you so much to those who helped in this research, especially for our Proofreaders, The Typists, and then the sectio caesaria patients at the Ciputat Buah Hati Hospital.

\section{REFERENCES}

Balitbang Health Ministry of Indonesia. (2013). Basic Health Research. Jakarta: Balitbang Kemenkes RI

Dahlan, M. S. (2013). Besar Sampel Dan Cara Pengambilan Sampel Dalam Penelitian Kedokteran Dan Kesehatan. Jakarta: Salemba Medika

Farada and Amalia, R. (2011). Pengaruh Teknik Relaksasi Autogenik Terhadap Tingkat Kecemasan Pada Ibu Primigravida Trimester III Di Wilayah Kerja Puskesmas Kotakulon Kabupaten Bondowoso. Universitas Jember

Fithriana, Marvia, D. E and Putra, A. A. (2016).
Perbandingan Pemberian Terapi Relaksasi Autogenic Dan Aroma Terapi Terhadap Penurunan Tingkat Nyeri Haid (Dismenore) Pada Siswi Di MTSNW Samawa Sumbawa Besar. Journal Prima. Vol.2(2) pp-1-10

Goldbeck and Schmid K. (2003). Effectiveness of autogenic relaxation training on children and adolescents with behavioral and emotional problems. Journal ot the American Academy of Child \& Adolescent Psychiatry. Vol 42(9):1046-54.

Hashim, H. A and Hanafi H. (2011). The Effects of Progressive Muscle Relaxation and Autogenic Relaxation on Young Soccer Players' Mood States. Asian Journal of Sports Medicine. Vol 2(2): 99-105.

Heriana, P. (2014). Buku Ajar Kebutuhan Dasar Manusia. Tangerang Selatan: Binarupa Aksara Publisher

Hidayat, A and Uliyah, M. (2016). Basic Nursing Book. Jakarta: Salemba Medika

Sriyanti, C. (2016). Pengaruh Mobilisasi Dini Terhadap Proses Penyembuhan Luka Post SC Di Rumah Sakit Umum Daerah Dr. Zainoel Abidin Banda Aceh. Journal Pionir Vol 3(2) pp-85-90

Tiana, Y. (2014). The Effect of Autogenic Relaxation in the Nursing Intervention to The Level of Anxiety in the Pra Operation Surgical in Ungaran Local Hospital. Ngudi Waluyo UngaranUniversity: Thesis

Yusuf, M. (2014). Research Method: Quantitatve, Qualitative and Mix Method Research. Jakarta: Kencana Preadamedia Group 